RENATA HOŁDA ${ }^{1}$

\title{
PIĘKNA CESARZOWA... ELŻBIETA BAWARSKA (SISI) I JEJ PERFORMANSE
}

Słowa kluczowe: cesarzowa Elżbieta Bawarska, Sisi, Cesarstwo Habsburgów, obrazy kobiecości, publiczne performanse

W artykule prezentuję postać Elżbiety Bawarskiej (Sisi) - żony Franciszka Józefa I. Przeszła ona do historii jako kobieta piękna i nieszczęśliwa. „Piękna cesarzowa" to moim zdaniem rola, którą skonstruowała dla siebie ta bohaterka i którą konsekwentnie realizowała, odtwarzając serie publicznych performansów i tworząc aktywnie własny publiczny wizerunek. Korzystała przy tym z możliwości, jakie dawały jej pozycja, finanse i wpływy cesarzowej. Ostatecznie wizerunek, który stworzyła i który starała się kontrolować, przesłonił historyczną postać cesarskiej małżonki, a jego elementy funkcjonują w kulturze także współcześnie.

Cesarzowa Elżbieta, zwana przez bliskich Sisi, przeszła do historii jako kobieta piękna i nieszczęśliwa. Mit, który zaczął się kształtować wkrótce po jej tragicznej śmierci, zawierał elementy mieszczańskiej krytyki dworu. Późniejszy upadek naddunajskiej monarchii i koniec epoki, który wyznaczyła pierwsza wojna światowa, sprawiły, że życie żony Franciszka Józefa, podobnie jak inne dynastyczne nieszczęścia, odbierane było jako antycypacja i metafora nadchodzącego rozpadu. Do odnowienia i popularyzacji mitu przyczyniła się trylogia filmowa Ernsta Marischki², do dzisiaj chętnie oglądana nie tylko w krajach niemieckich, łącząca w sobie opowieść o Kopciuszku z Bawarii z nostalgiczną wizją habsburskiej belle époque. W następstwie

\footnotetext{
${ }^{1}$ Dr; Uniwersytet Jagielloński; ORCID: 0000-0003-1019-2555; renata.holda@uj.edu.pl.

${ }^{2}$ Składają się na nią trzy filmy: Sissi (1955), Sissi - młoda cesarzowa (1956) oraz Sissi - losy cesarzowej (1957). Rolę Elżbiety zagrała Romy Schneider, a Franciszka Józefa Karlheinz Böhm.
} 
tych oddziaływań osoba dziewiętnastowiecznej cesarzowej przeobraziła się w bajkową postać księżniczki Sissi ${ }^{3}$. Elementem tego znanego i rozpoznawalnego mitu, eksploatowanego nadal przez kulturę popularną, ważnego dla austriackiej turystyki i przemysłu pamiątkarskiego, jest - jak zauważyła Juliane Vogel - celebrowanie odmienności ${ }^{4}$. Ja jednak chciałabym wrócić do historycznej postaci, kobiety, która fascynowała i wywalczyła dla siebie autonomię, żyjąc - tak twierdzili współcześni - „jak chciała”. Konstatacja taka nie oznaczała braku krytyki, powszechnie uznawano bowiem, że Elżbieta nie spełniła nie tylko społecznej roli władczyni wielonarodowego cesarstwa, lecz również żony i matki. Dzisiaj wyrażana niegdyś dezaprobata nie ma znaczenia, przysłonięta wizją uroczej i dobrej Sissi, niemającej jednak wiele wspólnego z historycznym pierwowzorem. Wiele wskazuje na to, że rzeczywista cesarzowa była nie tylko „porywająco piękna”, ale także trudna w relacjach, stanowcza i artykułująca własne cele.

„Piękna cesarzowa” to moim zdaniem rola, którą skonstruowała dla siebie Elżbieta i którą konsekwentnie realizowała, odtwarzając serie publicznych performansów, korzystając zarówno z możliwości, jakie dawała jej wysoka pozycja cesarskiej małżonki, jak i dostępne w jej czasach media - przede wszystkim fotografia i prasa - ich możliwości reprodukcji oraz masowa dystrybucja.

\section{CESARZOWA ELŻBIETA}

Elżbieta urodziła się w 1837 roku w rodzinie Wittelsbachów, jednej z najstarszych niemieckich dynastii, panującej w Bawarii, a wcześniej także w kilku innych państwach europejskich ${ }^{6}$.

${ }^{3} \mathrm{~W}$ artykule stosuję rozróżnienie - mówiąc o "Sisi” (jedno 's' w środku), mam na myśli historyczną postać, do której w ten sposób zwracali się najbliżsi (również jako „Lisi”). Zdrobnienia „Sissi” (podwójne 's') używam zaś, gdy piszę o postaci z mitu. Tę drugą wersję imienia rozpropagowała wspomniana trylogia Marischki.

${ }^{4}$ R. Schulte, The Queen - A Middle-Class Tragedy. The Writing of History and the Creation of Myths in Nineteenth-Century France and Germany, "Gender \& History" 2002, t. 14 , s. 285.

${ }^{5}$ E. Crankshaw, The Fall of the House of Habsburg, New York, NY 1963, s. 105.

${ }^{6}$ Geschichte des Hauses Wittelsbach, https://haus-bayern.com/geschichte (dostęp 5 III 2021). 
Szerzej dała się poznać, gdy podczas spotkania zaaranżowanego latem 1853 roku w Ischl swoją osobą zainteresowała młodego cesarza Austrii Franciszka Józefa, który właśnie ją, a nie przygotowywaną do tego awansu jej starszą siostrę Helenę, wybrał na swoją żonę. W dniu pospiesznych zaręczyn narzeczona liczyła sobie piętnaście lat. Małżeństwo zawarte rok później nie było jednak szczęśliwe. Nastolatka przeniesiona w obce środowisko, z dala od najbliższych i od dotychczasowego liberalnego stylu życia, w krótkim czasie urodziła troje dzieci. Była nieśmiała, zagubiona, nie do

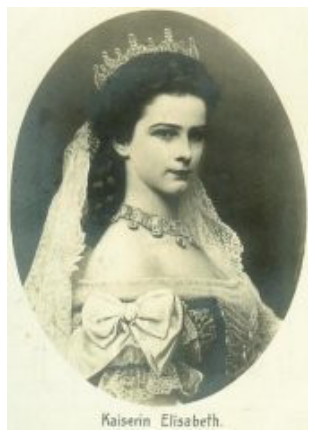

II. 1. Cesarzowa Elżbieta w węgierskiej sukni koronacyjnej. Pocztówka z reprodukcją obrazu Georga Raaba (1867) końca rozumiała się z wymagającą teściową i z mężem, który w burzliwym okresie, jaki przechodziło państwo, którym władał, nie mógł poświęcić jej wystarczająco dużo czasu. Nie umiała również odnaleźć się na wystawnym wiedeńskim dworze, dostosować do formułowanych pod jej adresem oczekiwań, obowiązków reprezentacyjnych oraz sztywnej etykiety będącej częścią habsburskiej tradycji. Tajemnicza, być może - jak podejrzewali współcześni - symulowana choroba7, na którą zapadła cesarzowa w 1860 roku, sprawiła, że wyjechała na dłuższy czas z Wiednia. Chociaż po ponad dwóch latach ${ }^{8}$ wróciła $w$ rozkwicie urody, bardziej dojrzała, pewniejsza siebie i własnej kobiecości, jej długotrwałe wyjazdy stały się codziennością, nie przysparzając jej zwolenników, podobnie jak systematyczne unikanie powinności towarzyskich i tych, które wynikały z jej pozycji społecznej cesarzowej, uznawanej za „matkę narodu”. Brak regularnych „pojawień się” Elżbiety powodował plotki, dezorganizował życie dworu oraz wywoływał niezadowolenie i krytykę wśród poddanych, którzy oczekiwali jej publicznej obecności ${ }^{9}$. Ponadto podawał w wątpliwość pozycję Franciszka Józefa jako głowy rodziny, trwałość związku panującej pary i jej możliwości zapewnienia trwałej dynastycznej sukcesji, co uznawane było za podstawowy obowiązek cesarskiej małżonki.

\footnotetext{
${ }^{7}$ B. Hamann, Cesarzowa Elżbieta, przeł. J. Koźbiał, Warszawa 1999, s. 130-131.

${ }^{8}$ W sierpniu 1862 roku. Zob. Ibidem, s. 148-149.

${ }^{9}$ Ibidem, s. 245-246.
} 


\section{FOTOGRAFIE}

Podczas pobytu na dobrowolnym „wygnaniu”, na Maderze, Korfu, a później w Wenecji, Sisi zaczęła tworzyć swoje kolekcje. Zbierała kamee i obrazy oraz fotografie $\mathrm{w}$ modnym wówczas formacie cartes-de-visite ${ }^{10}$. Interesowały ją reprodukcje dzieł sztuki, przede wszystkim jednak portrety pięknych kobiet. Modelki niekoniecznie musiały wywodzić się z najwyższych warstw społecznych, wręcz przeciwnie, Elżbietę zajmowały również urodziwe kobiety o plebejskich korzeniach, mieszczanki, aktorki, baletnice i tancerki, artystki cyrkowe, a zatem osoby biorące udział w różnych rodzajach płatnych występów. Reprezentowały one zawody, które nie cieszyły się w tych czasach najlepszą reputacją, a wykonujące je kobiety często były uznawane za osoby podejrzane moralnie i identyfikowane jako prostytutki. W uzupełnianie zbiorów zaangażowana była rodzina cesarzowej, a także austriaccy dyplomaci pracujący w zagranicznych placówkach ${ }^{11}$. Cesarzowa nie tylko zleciła nadsyłanie fotografii, ale - o czym świadczy jej korespondencja ${ }^{12}$ - sama $z$ dostarczonych materiałów wybrała pewną ich część i zaaranżowała wygląd albumów, a w ich obrębie układ cartes de visite. Traktowała je jako prywatną własność nieprzeznaczoną do upubliczniania, która po jej śmierci trafiła do spadkobierców cesarzowej i była w ich posiadaniu do 1978 roku $^{13}$. Dzisiaj osiemnaście z nich znajduje się w Muzeum Ludwig w Koloniii ${ }^{14}$. Wśród nich są trzy "Albumy piękności” („Schönheiten-Alben"), w których obok członków rodziny, arystokratek i głów koronowanych umieściła zdjęcia kobiet „z półświatka” ${ }^{15}$. Współcześnie zbiory te budzą zainteresowanie nie ze względu na swoją jakość - ta często

${ }^{10}$ Cartes de visite zostały opatentowane w 1854 roku przez francuskiego fotografa André Adolphe'a Eugène'a Disdériego. Miały format 4,5 × 2,5 cala. Szybko stały się nie tylko środkiem reprezentacji chętnie wykorzystywanym przez arystokratów i mieszczaństwo, ale również przedmiotami kolekcjonerskimi.

${ }^{11}$ Zob. B. Hamann, Cesarzowa Elżbieta, op. cit., s. 165-166.

12 Ibidem, s. 165.

${ }^{13}$ A. Matzker, E. Schlesinger, Sissi (Sisi) privat - Bisher unbekannte Photoalben der Kaiserin, https://onlinemerker.com/sissi-privat-bisher-unbekannte-photoalben-derkaiserin/ (dostęp 5 III 2021).

${ }^{14}$ Sisi's Photos Reveal an Emancipated Empress, https://www.dw.com/en/sisis-photos-reveal-an-emancipated-empress/a-55398188 (dostęp 5 III 2021).

${ }^{15}$ Sisi in Private. The Empress's Photo Albums October 24, 2020 - July 4, 2021 [wystawa], https://www.museum-ludwig.de/en/exhibitions/sisi-privat-die-fotoalben-der-kaiserin.html (dostęp 5 III 2021). 
jest kwestionowana - i nie dlatego, że ilustrują jedną z „manii” Elżbiety (przez jej biografkę określaną jako kult piękna ${ }^{16}$ ), lecz z powodu możliwości odczytania zawartych w nich treści tożsamościowych oraz wrażliwości pierwszej właścicielki na kwestie klasy i płci.

Zdaniem Miriam Szwast, kuratorki wystawy prezentującej tę kolekcję, śledzącej związki między kolekcjonowaniem podobizn kobiet a poglądami cesarzowej na temat kobiecego piękna i stworzonym przez nią autowizerunkiem, ogląd tych fotografii ujawnia „prawdziwe ja” cesarzowej, jej inny, nieznany obraz. „To, czego doświadczamy dzięki albumom, to Elżbieta, która uważnie obserwuje, ma ostry język, która potrafi być kąśliwa i cyniczna - i która zdecydowanie jest chętna do eksperymentowania"17.

Jak chcą dzisiejsze badaczki, celem działań Elżbiety nie było po prostu kolekcjonerstwo, a trudny emocjonalnie okres, w jakim rozpoczęła zbieranie, poprzedzający jej zauważaną przez biografów metamorfozę, daje wskazówki do odczytania znaczenia tego procesu:

Pociechy i stabilności w tym burzliwym czasie szukała w praktyce kolekcjonowania fotograficznych cartes-de-visite. W swojej analizie dostrzegam następujące tematy przyczyniające się do jej procesu stawania się podmiotem: (1) fotografie sugerujące autorefleksyjną świadomość kobiet $w$ roli widzów i inscenizowanych przez siebie spektakli, (2) fotografie mieszczanek i szlachetnych dam, które projektują poczucie komfortu w swojej narracji o wspólnocie, (3) „nieporządne/nieuporządkowane” fotografie, które sugerują poczucie rozbawienia na temat zdolności fotografii do projekcji „prawd” o burżuazyjnym/ szlacheckim szacunku, (4) fotografie, które w ich „nieporządnych/nieuporządkowanych" zestawieniach alternatywnego scenariusza społeczno-politycznego i płciowego sugerują bunt przeciwko roli Sisi jako cesarzowej, żony i matki ${ }^{18}$.

Zdaniem przywołanej wcześniej kuratorki tak powstałą kolekcję można traktować jako „wizualny dziennik”19 zdradzający fascynację Elżbiety rela-

${ }^{16}$ B. Hamann, Cesarzowa Elżbieta, op. cit., s. 162-184.

17 D. Stender, Sisi als Influencerin. Die Foto-Alben der Kaiserin im Kölner Museum Ludwig, wywiad z 23 X 2020, https://www.swr.de/swr2/kunst-und-ausstellung/sisi-als-influencerin-die-foto-alben-der-kaiserin-im-koelner-museum-ludwig-100.html (dostęp 5 III 2021).

${ }^{18}$ B. Muellner, Empress Elisabeth and Her "Untidy" Collection, „Women's Studies" 2010, t. 39, s. 539-540.

${ }^{19}$ Ch. Driessen, Sisi privat. Faszinierendes Bild der Kaiserin in Köln, „Aachener Nachrichten" 23 X 2020, https://www.aachener-nachrichten.de/kultur/kunst/ 
cjami między widzeniem a byciem widzianym, pokazywaniem się publicznym oraz byciem obiektem obserwacji i podziwu. Ujawnia, że rozumiała ona zasady autoprezentacji. „Była świadoma i interesowała się warstwami znaczenia i performansu $w$ doświadczeniu wizualnym"20.

Kolekcjonowanie było ważnym etapem zdobywania przez Sisi samoświadomości, elementem konstruowania siebie, ale również rozpoznania wpływu nakazowego piękna na kobiece wizerunki:

[...] wszystkie kobiety królewskiego rodu podlegały tak skomplikowanym strojom i rytuałom, a liczba podobnych zdjęć znalezionych w albumach świadczy o świadomości tego, jak tożsamość jest konstruowana ze wspólnych społecznych oczekiwań co do płci, klasy i tak dalej. Z tej perspektywy zdjęcia Sisi być może pozwoliły jej uświadomić sobie, że wiele kobiet $z$ jej otoczenia również brało udział w tym przedsięwzięciu self-performances $w$ oparciu o ekstremalne codzienne zabiegi pielęgnacyjne ${ }^{21}$.

Kolekcjonując portrety, Sisi odkryła fotografię jako środek reprezentacji, nabywając jednocześnie świadomość istnienia związków między inscenizacją i prezentowaniem siebie. Piękne kobiety uwiecznione na zdjęciach $\mathrm{i}$ „demokratycznie" zgromadzone w jednym zbiorze umożliwiły cesarzowej zrekonstruowanie i w następstwie dostosowanie się - choć na własnych zasadach - do normatywnych standardów piękna, co okupione zostało codziennym reżimem i długotrwałymi zabiegami mającymi na celu zachowanie urody i zgrabnej sylwetki.

Zbieraniu fotografii oraz namysłowi nad przedstawionymi na nich kobietami towarzyszyła refleksja cesarzowej dotycząca jej roli i publicznych performansów, a także na temat własnych możliwości i wpływów. Świadomość prowadzenia życia "na pokaz", to znaczy wystawiania się na widok publiczny, by być oglądaną, Sisi wykazywała już wcześniej. Zobowiązywała ją do tego jej wysoka pozycja społeczna i kulturowa rola cesarzowej, co nie znaczy, że akceptowała to czy lubiła. „Jestem na pokaz jak dziwadło w cyrku”22 - mówiła jeszcze jako cesarska narzeczona. Także później „odczuwała drogocenne ubrania, które nosiła przy oficjalnych okazjach, jako rodzaj

sisi-privat-faszinierendes-bild-der-kaiserin-in-koeln_aid-54202847 (dostęp 5 III 2021).

${ }^{20}$ B. Muellner, Empress Elisabeth..., op. cit., s. 552-553.

${ }^{21}$ Ibidem, s. 553.

22 J. Bowers Bahney, Stealing Sisi's Star. How a Master Thief Nearly Got Away with Austria's Most Famous Jewel, McFarland, CA 2015, s. 16. 
maskarady, mówiła o "uprzęży» [Geschirr], w której ją umieszczano"23, innym razem mówiła o „mundurze”, co sugeruje, że powinności te traktowała jako formalną i wymagającą służbę.

Zbierając fotografie piękności swych czasów, najprawdopodobniej zupełnie świadomie, na ich podstawie Sisi ukształtowała własny wizerunek publiczny, którego wzorem były popularne w tym czasie aktorki i kobiety „podejrzanej konduity”24. Świad-

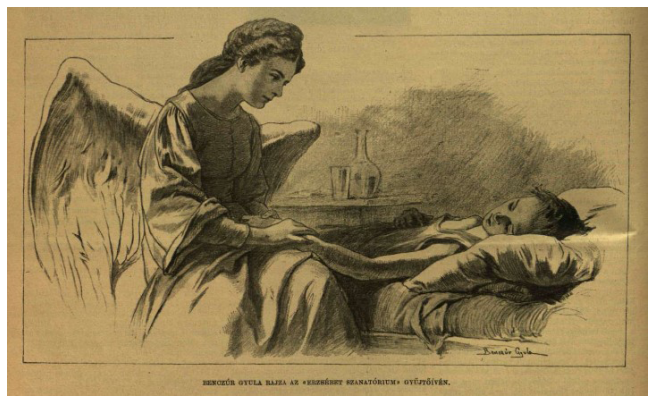

II. 2. Sisi jako anioł miłosierdzia. Ilustracja prasowa według rysunku Gyuli Benczúra, źródło: „Vasárnapi Ujság”, vol. 47: 1900, nr 47 (November 25), s. 776. czy to o dystansie Elżbiety do społecznie sankcjonowanych etykiet, a także o rozpoznaniu kulturowego i społecznego uwarunkowania „piękna”. Wizerunek przeznaczony był na użytek tych, którzy chcieli ją oglądać, lecz Sisi starała się sprawować nad nim kontrolę. Było to możliwe nie tylko ze względu na jej osobiste starania, lecz również dlatego, że wpisywało się w szerszą praktykę manipulowania publicznym wizerunkiem cesarza i jego rodziny, jaką prowadził dwór, po doświadczeniach rewolucji próbujący odnaleźć nowy sposób nawiązania więzi z poddanymi. Władcy starali się zachować swoją pozycję polityczną i społeczną, zrezygnowali częściowo z ukazywania swego splendoru i podkreślania boskiego powołania do sprawowania władzy, demonstrując w zamian publicznie swoje przywiązanie do wartości rozrastającej się klasy średniej, w tym pochwałę szczęścia rodzinnego. Ułatwiała to możliwość kontrolowania prasowych doniesień o Habsburgach, co kontynuowano nawet, gdy pod koniec lat 60. XIX wieku zlikwidowano cenzurę. Z drugiej strony same gazety chętnie publikowały poszukiwane przez czytelników materiały dotyczące monarszej rodziny, tym samym uczestnicząc w promocji cesarskiej popularności i nowego oblicza monarchii ${ }^{25}$.

${ }^{23}$ Ch. Driessen, Sisi privat..., op. cit.

${ }^{24}$ O. Gruber-Florek, The Modern Monarch. Empress Elisabeth and the Visual Culture of Femininity 1850-1900. Dissertation submitted to the Graduate School-New Brunswick Rutgers, The State University of New Jersey 2021, s. 86, https://rucore.libraries.rutgers. edu/rutgers-lib/37535/PDF/1/play/ (dostęp 6 III 2021).

${ }^{25}$ P.M. Judson, The Habsburg Empire. A New History, Cambridge, MA 2016, s. 237. 
Elżbieta miała wpływ na powstanie swych najsłynniejszych przedstawień ikonograficznych, wskazując mistrzowi pozy i ujęcia, w jakich chciała być ukazana. Wykorzystała w tym wiedzę dotyczącą obrazów piękna, którą dało jej kolekcjonowanie fotografii. Olivia Gruber-Florek wykazała, że w tworzeniu swego wizerunku Sisi inspirowała się portretami pięknych kobiet ze swoich albumów, ich ubiorami i tym, w jaki sposób prezentowały swoją fizyczność: twarz, ciało i włosy ${ }^{26}$. Jeżeli wizerunek powstał - na co cesarzowa pozwalała niechętnie i rzadko - dbała, aby był odpowiednio rozpropagowany, tym samym stając się „konstruktorem historycznych wizji"27.

\section{SUKNIA OD WORTHA}

Najbardziej znane i często kopiowane trzy obrazy przedstawiające cesarzową Elżbietę wyszły spod pędzla Franza Xavera Winterhaltera w latach 1864-1865. Namalował on jeden portret oficjalny - przeznaczony do rozpowszechniania - i dwa prywatne, pomyślane jako prezent dla Franciszka Józefa, które - choć znane - w przeszłości nie były reprodukowane tak często.

Szczególnie ważny jest portret cesarzowej wybrany jako jej oficjalny wizerunek, a więc również element propagandy państwowej. Z czasem stał się on tak rozpowszechniony, że przedstawiona na nim postać skutecznie przesłoniła zarówno wcześniejsze podobizny Sisi, jak i późniejsze jej portrety. Pod wieloma względami różni się on od wielu innych wizerunków władców i ich żon, zrywając z tradycją monarchistycznych reprezentacji.

Obraz odtwarzał stylizację, w której Elżbieta pojawiła się kilka miesięcy wcześniej na balu poprzedzającym ślub swego brata Karola Teodora w 1864 roku w Dreźnie i w której zrobiła oszałamiające wrażenie ${ }^{28}$. Cesarzowa przedstawiona jest na nim w najmodniejszej wówczas białej satynowej kreacji „Robe aux Étoiles” („Suknia z gwiazdami”), pochodzącej najprawdopodobniej z paryskiego atelier mody Charlesa Wortha, uznawanego dziś za twórcę haute couture. Projekty Charlesa Wortha, który sam był postacią niejednoznaczną, przekraczającą podziały społeczne i różnice płci,

${ }^{26}$ O. Gruber-Florek, The Modern Monarch..., op. cit.

${ }^{27}$ B. Muellner, Empress Elisabeth..., op. cit., s. 540.

${ }^{28}$ J. Bowers Bahney, Stealing Sisi's Star..., op. cit., s. 65; E.C. Corti, Cesarzowa Elżbieta, przeł. Z. Peteresowa, Warszawa 1938, s. 104; B. Hamann, Cesarzowa Elżbieta, op. cit., s. 170. 
jako Anglik i mężczyzna zajmujący się modą dla kobiet wprowadzający ferment w świat uznawany za ich domenę, charakteryzowały się bogactwem i nadmiarem. Wykorzystywał "luksusowe tkaniny i z przepychem skonstruowane kształty, które były wysoko cenione przez jego klientów i dyskredytowane przez jego krytyków"29. Uważał się za artystę (co podkreślał ubiorem charakterystycznym dla paryskich malarzy) oraz twórcę nie tylko projektów, ale i ich nabywczyń, a także sukcesów towarzyskich, jakie odniosły, nosząc jego kreacje. Suknia, którą zaproponował Elżbiecie, odsłaniała ramiona, szeroka krynolina spowita była warstwami delikatnego tiulu z naszytymi nań srebrnymi gwiazdami. Ozdoby w tym samym kształcie - brylantowe spinki wykonane przez dworskiego jubilera Alexandra Emanuela Köcherta - miała Elżbieta wpięte we fryzurę ułożoną z grubych warkoczy, która stała się w ciągu kolejnych lat jej znakiem rozpoznawczym. Jeszcze wiele lat później prasa popularna charakteryzowała tę często naśladowaną koafiurę jako „potrójny dyadem z cudnych kruczych warkoczy”30, a biżuteria w kształcie gwiazd stała się słynnym i poszukiwanym dodatkiem ${ }^{31}$.

Jednak wybór tego właśnie portretu jako oficjalnej podobizny władczyni, o czym prawdopodobnie zdecydowała ona sama, musi zaskakiwać. Winterhalter był oczywiście już wcześniej autorem nawet bardziej nieformalnych przedstawień panujących kobiet (chociażby królowej brytyjskiej Wiktorii i samej Elżbiety), jednak w przeciwieństwie do wizerunku cesarzowej Austrii, nie były one przeznaczone do szerszego rozpowszechniania i nie miały statusu „państwowego".

Portrety, nawet realistyczne, oraz fotografie nie są przedstawieniem indywidualności, lecz podlegają uwarunkowaniom kulturowym, w tym normatywnym standardom piękna, które tworzą rodzaj maski, wpływając na wygląd przedstawianej osoby. Do „noszenia” tej maski, powielanej przez kolejne reprezentacje, zobowiązywały Elżbietę jej pozycja społeczna i rola

${ }^{29}$ A. Joseph, "A Wizard of Silks and Tulle". Charles Worth and the Queer Origins of Couture, „Victorian Studies” 2014, t. 56, nr 2, s. 257.

${ }^{30}$ Kilka rysów z prywatnego życia panujqcych kobiet, „Dwutygodnik dla Kobiet” 1881, R. 1, nr 22 (23 VII 1881), s. 230.

${ }^{31}$ Istniejąca do dziś wiedeńska Köchert kilka lat temu ponownie wprowadziła do sprzedaży wielofunkcyjne ozdoby w kształcie gwiazd wykonane według oryginalnych wzorów z XIX wieku. Jak podano, zostały wznowione „w hołdzie nietuzinkowej kobiecie”. Zapewne innym, mniej eksponowanym powodem jest stałe zainteresowanie turystów tego rodzaju wyrobami. Zob. Die Sterne der Kaiserin Elisabeth, https://www.koechert. com/sisis-sterne/ (dostęp 29 VII 2021). 
cesarzowej32. W przypadku omawianej podobizny nietypowa jest jednak zarówno poza, w której mistrz przedstawił Sisi, jak i fakt, że na obrazie brakuje jakichkolwiek elementów sugerujących pozycję społeczną przedstawionej kobiety, herbów, insygniów oraz alegorii łączonych z władzą i z funkcją jej cesarskiego małżonka, co w przypadku panujących monarchów oraz ich oficjalnych portretów było powszechną i oczekiwaną praktyką. Z boku tylko pojawia się śródziemnomorska roślina - kwitnący oleander, o niejasnej symbolice, być może aluzja do pobytu Elżbiety na Korfu. Zamiast pewnej dosłowności charakteryzującej inne monarsze portrety, wskazujące wyraźnie na pozycję i rolę modela, podkreślające ją strojem i symbolami władzy, akcentującymi jego (prawdziwe lub nie) osiągnięcia i możliwości, portret Elżbiety operował niedopowiedzeniem, zachęcał widza do interakcji i zostawiał wiele miejsca na fantazje. Olivia Gruber-Florek, analizująca najsłynniejsze portrety Sisi, tak pisała o tym przedstawieniu malarskim:

[...] na portrecie państwowym Winterhaltera władza [authority] Elżbiety emanuje raczej z jej piękna niż z jakiegokolwiek związku z mężem. Elżbieta pojawia się bez korony ani regaliów, które symbolizują jej status; jej prowokacyjna pozycja, kaskadowa suknia i zalotna postawa sugerują zamiast tego performans, w którym kontroluje relacje z widzami. Takie współistnienie erotyzmu i władzy jest bezprecedensowe w portretach państwowych kobiet-monarchiń, w większym stopniu dopasowując obraz do kanonicznych obrazów dziewiętnastowiecznej kobiecości, które ukształtowały historyczne rozumienie modernizmu w sztuce ${ }^{33}$.

Obraz nie jest reprezentacją władzy cesarskiej i jej dostojeństwa, ale demonstracją piękna. Elżbieta patrzy wprost na widza, co zdaniem cytowanej badaczki wskazuje na świadomość „bycia oglądaną" ${ }^{\prime 34}$. Z portretu emanuje jej pewność siebie oraz własnej atrakcyjności.

Jest prawdopodobne, że Elżbieta miała bezpośredni wpływ na powstanie tej podobizny, wybierając zarówno strój, jak i pozę. W istocie jest jej autoprezentacją, choć zwizualizowaną za sprawą mistrza dworskiego portretu. Wiadomo, że starannie dopierała ubiory i ujęcia, w których chciała być portretowana, na co pozwalała niechętnie i rzadko, odmawiając również pozowania do zdjęć rodzinnych i fotografii z dziećmi. Można zatem przyjąć,

\footnotetext{
${ }^{32}$ B. Muellner, Empress Elisabeth..., op. cit., s. 552-554.

${ }^{33}$ O. Gruber-Florek, The Modern Monarch..., op. cit., s. 14.

${ }^{34}$ Ibidem, s. 125.
} 
że dzieło Winterhaltera i zawarte bądź niezawarte $w$ nim elementy przedstawiało rodzaj deklaracji dotyczący jej własnej osoby, a właściwie, w podwójnym sensie, obrazu, jaki chciała przedstawić. Wyłamując się z zasad rządzących portretem dworskim, czyli także z tego, co - $\mathrm{w}$ sensie wizualnym i symbolicznym - oznaczało "być" cesarzową, Sisi zaznaczyła swą osobowość, indywidualność i pewną niezależność, wskazując na własne priorytety, wśród których wysoka pozycja cesarskiej małżonki (rodzaj "urzędu") wydawała się drugorzędna wobec potęgi urody, elegancji i pewnej kokieterii. Portret Elżbiety można traktować jako symboliczne odrzucenie uniwersalizującej roli cesarzowej czy przedstawicielki dynastii, kolejnej "figury" w ciągu wyobrażeń i tradycji monarchów Dei Gratia. Ujawnia on również rolę, jaką chciała odgrywać zainteresowana: indywidualności, przede wszystkim kobiety pięknej i zjawiskowej, celebrytki - w nowoczesnym tego słowa znaczeniu. Zdaniem Olivii Gruber-Florek obraz jest również manifestacją kontroli, jaką uzyskała Elżbieta nad swoim ciałem,

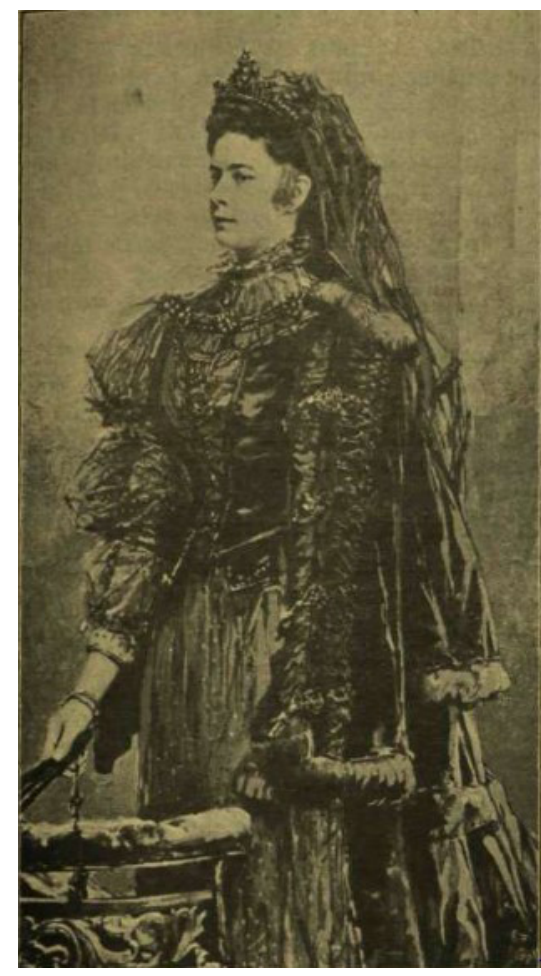

II. 3. Ilustracja prasowa przedstawiająca cesarzową Elżbietę podczas obchodów tysiąclecia Węgier. Kolaż powstały w pracowni Sandora Sterlickiego. Źródło: „VASÁRNAPI UJSÁG”, .45: 1898, nr 38 (18.09), s. 657 ukształtowanym zgodnie z wybranym przez nią modelem ${ }^{35}$. „Kontrola” oznaczała nie tylko wprowadzenie reżimu żywieniowego, forsownych ćwiczeń gimnastycznych i ryzykownych zabiegów mających podkreślić i podtrzymać urodę, ale również odmowę prokreacji. $\mathrm{Na}$ ten ostatni fakt wskazuje chociażby różnica między narodzinami następcy tronu arcyksięcia Rudolfa (1858) a kolejnego, „węgierskiego” dziecka - Marii Walerii (1868), która miała być rodzajem prezentu dla męża i Węgier.

${ }^{35}$ Ibidem, s. 32. 


\section{INSCENIZACJE ${ }^{36}$}

Elżbieta konsekwentnie stroniła od wszelkich uroczystości dworskich i świąt, niekiedy nawet lekceważąc i łamiąc uprzednio przyjęte zobowiązania. Tym z większą uwagą obserwowano i relacjonowano jej rzadkie wystąpienia publiczne.

Jedną z okazji łączących się z udziałem cesarzowej, komentowaną szeroko przez prasę, była koronacja cesarskiej pary na króla i królową Węgier. Była ona uwieńczeniem i przypieczętowaniem pojednania z tym krajem, w czym miała swój znaczący udział także Sisi i co uważała za swoje zwycięstwo $^{37}$. "Cesarzowa, mimo bladej cery, imponująca i nader ujmująca piękność" ${ }^{38}$ niewątpliwie była atrakcją tych uroczystości. Zachwyciła ona obserwatorów w drugi dzień uroczystości koronacyjnych w Budzie (9 czerwca 1867), będący nie tylko okazją do odprawienia monarchicznych rytuałów, lecz dający również możliwość autoprezentacji, w której dużą rolę odgrywał luksusowy i nasycony znaczeniami strój:

Cesarz, który prowadził pod rękę cesarzową, był w ubiorze marszałka węgierskiego. N. Pani miała białą suknię (moire), okrytą brukselskiemi koronkami, dyadem i naszyjnik z drogich kamieni i woal z koronek brukselskich. Za królem i królową szli arcyksiążęta i najbliższe otoczenie dworskie. Cesarzowa była dziś czarująco piękną, i najlepiej się mogłem przekonać, jak wielkie wrażenie musiała na niej zrobić koronacya, bo wczoraj była zupełnie wybladłąa

Koronacyjna suknia Elżbiety, dzisiaj określana jako „węgierska” lub nawet "ludowa"40, pochodziła z pracowni Charlesa Wortha i mimo że zawierała elementy nawiązujące do stroju Węgrów, była dziełem wielkiego kreatora. Oczywiście, jej detale oraz ogólny wydźwięk były przemyślane i zapewne wymagane przez zamawiającą, cytującą patriotyczną modę Węgrów, co składało się na rodzaj hołdu i wyrazu poparcia dla tego narodu, którego

${ }^{36}$ Terminu ,inscenizacja” używam w znaczeniu szerszym niż ściśle teatralne. Rozumiem ją jako coś, co sprawia, że „to, co pokazywane, zaczyna istnieć tu i teraz”. Zob. E. Fischer-Lichte, Estetyka performatywności, przeł. M. Borowski, M. Sugiera, Kraków 2008, s. 297.

${ }^{37}$ E.C. Corti, Cesarzowa Elżbieta..., op. cit., s. 135.

38 "Czas" 1867, R. 20, nr 133 (12 VI 1867), s. 2.

39 "Czas" 1867, R. 20, nr 134 (13 VI 1867), s. 3.

${ }^{40}$ A. Freifeld, Empress Elisabeth as Hungarian Queen, [w:] The Limits of Loyalty. Imperial Symbolism, Popular Allegiances, and State Patriotism in the Late Habsburg Monarchy, red. L. Cole, D. Unowsky, Brooklyn, NY 2009, s. 144 (Figure 6.2). 
interesy czynnie wyrażała Elżbieta. Sama kreacja była jednak dziełem „wysokiego krawiectwa” i przygotowana została, podobnie jak fotografie przedstawiające ustrojoną w nią cesarzową, z odpowiednim wyprzedzeniem.

I mimo swego nacjonalistycznego charakteru suknia koronacyjna z Domu Worth trafiała przede wszystkim w gusta operetkowe międzynarodowych wyższych sfer, które zachwycały się romantyczną i buntowniczą aurą węgierskiego salonowego heroizmu ${ }^{41}$.

Niezależnie od tego suknia była dobrze odczytywalnym ukłonem w stronę Węgrów, dawała również możliwość zaprezentowania indywidualnych upodobań politycznych cesarzowej, które stawiały ją w kontrze do reszty dworu, dobitnego wyrażenia jej preferencji i sympatii. Były one tak wymowne, że obserwatorzy porównywali królewską koronację do obrzędów ślubu i wesela, a Elżbietę - do oblubienicy ${ }^{42}$.

Mimo tego sukcesu cesarzowa nie angażowała się później w politykę. Chociaż zdobyła wyjątkową osobistą popularność na Węgrzech, gdzie często przebywała i doznawała nieomal czci, nie skorzystała z tej możliwości i nie stała się rzeczniczką pojednania działającą na rzecz wzmocnienia dualistycznej monarchii oraz pozycji dynastii Habsburgów w tym kraju. Uznawała się coraz częściej za osobę prywatną.

Jednak jeszcze wiele lat po koronacji w Budzie publiczne pojawienie się cesarzowej budziło sensację, także gdy były to mniejsze okazje. Ferdynand Hoesick, późniejszy pisarz i publicysta, bawiący latem 1881 roku w Wiedniu, miał okazję zobaczyć żonę Franciszka Józefa, wówczas kobietę czterdziestoczteroletnią, i pozostawił nieco chyba wyidealizowany opis tego wydarzenia:

Pamiętam, [...] żeśmy w operze byli na „Królowej Sabie” Goldmarka, na przedstawieniu galowym, na którym w cesarskiej loży siedząca cesarzowa Elżbieta tak mię [!] oczarowała swą pięknością, że wciąż oglądałem się w jej stronę, mniej interesując się królową Sabą na scenie ${ }^{43}$.

${ }^{41} \mathrm{~J}$. Vogel, The Double Skin. Imperial Fashion in the Nineteenth Century, [w:] The Body of the Queen. Gender and Rule in Courtly World 1500-2000, red. R. Schulte, Brooklyn, NY 2006, s. 224.

${ }^{42}$ A. Freifeld, Empress Elisabeth as Hungarian Queen..., op. cit., s. 151.

${ }^{43}$ F. Hoesick, Powieść mojego życia, t. 1, Wrocław - Kraków 1959, s. 249. 
$Z$ relacji wynika, że ówczesny nastolatek mógł obserwować bez przeszkód piękną cesarzową, co wydaje się jednak zaskakujące. Już wtedy rzadko pokazywała swoją twarz, przesłaniając ją welonem lub używając wachlarza, nawet wówczas, gdy jeździła konno.

Swoją sławę wiecznej piękności Elżbieta mogła zachować, tylko zapobiegając rozprzestrzenianiu się podobizn dokumentujących jej przemijającą urodę. Będąc w wieku około trzydziestu lat, zrezygnowała w ogóle z pozowania do jakichkolwiek portretów, a w decyzji tej pozostała konsekwentna do końca życia, nie pozwalając nie tylko uwieczniać swojej podobizny, lecz nawet się oglądać. Awersja do bycia portretowaną była podobno tak wielka, że Sisi nie zgodziła się kiedyś na zrobienie zdjęcia rentgenowskiego ${ }^{44}$.

Nie oznacza to, że portrety Elżbiety zniknęły ze sfery publicznej. Ponieważ nie było nowych, przez lata wykorzystywano jej wcześniejsze podobizny, a także posuwano się do oszustw. Późniejsze fotografie i litografie pojawiające się w prasie, jak również portrety, to impresje oparte na wcześniej powstałych obiektach, kolaże i fotomontaże powstałe z wykorzystaniem rozmaitych technik fotograficznych, w tym "składania” rodzinnego portretu Habsburgów z różnych i wykonanych w różnym czasie zdjęćc ${ }^{45}$. W sytuacji odmowy przez Elżbietę wytwarzania aktualnych podobizn były one jedynym sposobem uzupełnienia tego kłopotliwego braku i elementem kreowania wbrew faktom wzoru cesarzowej - przykładnej matki i wspierającej męża żony.

Elżbieta zdawała sobie sprawę, że o rozpoznaniu decydują pewne elementy, detale szczególne, które w powszechnym odbiorze składają się na „bycie cesarzową”. Uznawała zatem, że osoba wyposażona w odpowiednie atrybuty może zostać uznana przez publiczność za monarchinię - jeżeli pojawi się w odpowiedniej sytuacji, odpowiednio ubrana. Znanym faktem jest, że jej osobista fryzjerka Franziska (Fanny) Feifalik odgrywała niekiedy rolę cesarzowej, prawdopodobnie najczęściej podczas zagranicznych podróży, gdy ryzyko ewentualnego rozpoznania było najmniejsze ${ }^{46}$. Także inne epizody z życia cesarzowej Elżbiety ujawniają jej teatralne inspiracje.

${ }^{44}$ A. Menden, Sisi und ihre Schönheiten-Alben, „Süddeutsche Zeitung” 26 X 2020, https://www.sueddeutsche.de/panorama/fotos-koeln-kaiserin-sisi-1.5092956 (dostęp 5 III 2021).

${ }^{45}$ O. Gruber-Florek, The Modern Monarch..., op. cit., s. 58.

${ }^{46}$ B. Hamann, Cesarzowa Elżbieta, op. cit., s. 176. 
Publiczne okazje, na których się pojawiała, traktowała jako przedstawienia, w których odgrywała główną rolę. Stroje, w których pojawiała się podczas ważnych wystąpień publicznych, traktowała jak odpowiednio wystawne kostiumy, przekazujące przy tym dodatkowe znaczenia. Odkryta przez nią, z czasem mająca wpływy niewspółmierne do pozycji Fanny Feifalik była początkowo fryzjerką w teatrze, gdzie dała się poznać jako twórczyni pomysłowych fryzur występujących tam aktorek.

Pod koniec życia cesarzowa odsunęła się jeszcze bardziej od dworu i ludzi, co powodowało plotki i spekulacje dotyczące jej stanu zdrowia. W zagranicznej prasie pojawiały się wzmianki, że Elżbieta „straciła urodę i błyskotliwość umysłu"47.

Śmierć cesarzowej Elżbiety, zabitej 10 września 1898 roku w Genewie przez włoskiego anarchistę, odnotowały gazety w Europie i w Stanach Zjednoczonych, a doniesienia o szoku, jaki wywołało to wydarzenie, niewątpliwie nie były przesadzone ${ }^{48}$. Wiadomości o tym fakcie poruszyły również społeczeństwo galicyjskie, mimo że cesarzowa nigdy nie gościła $w$ tej prowincji. Nadejściu wieści o śmierci cesarzowej towarzyszył „niesłychany skandal w Krakowie":

Młody Adolf [Nowaczyński - R.H.] zareagował na tę wiadomość w sposób zupełnie nieoczekiwany. Wyskoczył na stół z triumfalnym okrzykiem „Vive l’anarchie!", po czym opuścił lokal - pod troskliwą opieką tajniaków. Zrobiła się niesłychana afera ${ }^{49}$.

W konsekwencji początkujący pisarz musiał opuścić Kraków i ukrywać się pod przybranym nazwiskiem za granicą, skąd wrócił po około dwóch latach.

Na pogrzebie cesarzowej wśród wielu żałobników obecna była delegacja galicyjska. Marszałek krajowy Stanisław Badeni złożył w imieniu Wydziału Krajowego wieniec z napisem „Wdzięczna Galicya”, Koło Polskie drugi

47 "The Weekly Union Times” 29 VII 1892, t. XXIII, s. 1.

${ }^{48}$ An Empress Slain, „Baxter Springs News” 17 IX 1898, t. 15, s. 2; All Europe Shocked, „The lola Register" 16 IX 1898, t. 32, s. 9; Empress's Assassin Jeers at Low. Ten of His Camrades Arrested, "New York Journal and Advertiser" 12 IX 1898, s. 1; The Murdered Empress, „The Sun” 11 IX 1898, s. 4.

${ }^{49}$ L. Solski, Wspomnienia, t. 2: 1893-1954, Kraków 1956, s. 229; zob. także M. Smolarski, Miasto starych dzwonów, Kraków 1960, s. 73. 
z napisem „Uwielbianej cesarzowej”50. Podobnych hołdów pochodzących z krajów cesarstwa i z innych państw było dużo więcej. Już wówczas uznawano losy cesarzowej za materiał na dzieło literackie: „Życie cesarzowej Elżbiety było jedną ciągłą zajmującą powieścią, miewało i swe akty strasznego dramatu, a zakończyło się okropnym epilogiem tragedii" ${ }^{\prime \prime}$. W doniesieniach prasowych z tego okresu odnaleźć można zarówno wzmianki o romantycznej miłości, która połączyła ją z Franciszkiem Józefem, jak i inne fragmenty, które do dzisiaj stanowią elementy kształtowanego wówczas mitu: „Do późnego wieku średniego była uważana za jedną z najpiękniejszych kobiet w Europie i była szczególnie dumna ze swoich długich włosów, opadających na ziemię, które lubiła nosić luźno, nawet przy publicznych okazjach"52.

\section{IMPERSONATORKA}

Impersonatorzy to osoby odtwarzające jakąś postać, czasem przeciwnej płci, wykorzystujący to wcielenie jako środek wyrazu oraz maskę lub fasadę, których elementem jest system gestów i zewnętrzny ubiór. Mogą one ukrywać wewnętrzną tożsamość lub ujawniać ją, w obu przypadkach wykazując, że kategoryzacje i zachowanie społeczne (nie tylko sceniczne) są występem i odgrywaniem kulturowo ustalonych ról ${ }^{53}$. Wyrazem napięcia wewnętrzne-zewnętrzne, rozdźwięku między ukrytym a manifestowanym, jest między innymi kamp.

Pojęcie kampu feministycznego zostało wprowadzone przez Pamelę Robertson w latach 90. XX wieku i dotyczyło tego, w jaki sposób kobiety wytwarzały i wykorzystywały do swoich celów kobiece reprezentacje

50 "Gazeta Kielecka” 21 IX 1898, R. 29, nr 75, s. 3.

${ }^{51}$ Cesarzowa Elżbieta, „Bluszcz" 17 (29) IX 1898, R. 34, nr 39, s. 1.

${ }^{52}$ The Murdered Empress, "The Sun" 11 IX 1898, s. 4.

${ }^{53}$ Zob. np. E. Newton, Wzorce ról, przeł. P. Czapliński, [w:] Kamp. Antologia przekładów, red. P. Czapliński, A. Mizerka, Kraków 2012, s. 469-490. Impersonacje kojarzą się współcześnie z subkulturą homoseksualną, transwestytyzmem lub drag, lecz historycznie rzecz biorąc, początkowo występy takie dotyczyły mężczyzn odtwarzających charakterystyczne role żeńskie („typy kobiece”, ujęte często mizoginicznie) w popularnym teatrze, w sytuacji gdy zabronione były występy kobiet, dopuszczone w Europie około 1660 roku, co oczywiście nie zakończyło tej tradycji trwającej w różnych „niskich” formach kulturowych. Przyjmuję szerokie rozumienie impersonacji jako wcielania się w kulturowo określoną rolę. 
w kulturze medialnej. Autorka sprzeciwiała się temu, aby słowa „kamp” używać wyłącznie w kontekście opozycyjnej mniejszości gejowskiej, wskazując, że mógł być on także kobiecą strategią sprzeciwu wobec wzorców patriarchalnych i norm dominujących w społeczeństwie. Kamp jako:

działanie strukturalne jest pokrewny feministycznym dyskusjom o konstruowaniu płci, performansie i wcielaniu w życie; tym samym można badać formę kampu jako praktykę feministyczną. Przejmując kamp dla kobiet, przywracam kobiecą formę estetyzmu, związaną z kobiecą maskaradą, która artykułuje i podważa procesy tworzenia obrazu i kultury, do których kobiety tradycyjnie mają dostęp $p^{54}$

Wspomniana wyżej „kobieca maskarada” daje okazję do podwójnej mimesis. Oznacza ona celowe powielanie kulturowych stereotypów płci i zgodę na rozpoznanie zgodnie z nimi, przy świadomości ich nieadekwatności w stosunku do własnej czy przedstawianej osoby. Komentując tę koncepcję opracowaną przez Mary Ann Doane, która stwierdzała jej inność w stosunku do występów typu cross-dressing lub drag, Pamela Robertson pisała:

W przeciwieństwie do nich koncepcja maskarady oferuje bardziej radykalny, parodystyczny potencjał. Zaskoczenie i nieodpowiedniość kobiecej maskarady tej samej płci [same-sex] polega na tożsamości płci [gender] maskarady i performerki - bawi się w bycie tym, za co już zawsze jest postrzegana ${ }^{55}$.

Tak rozumiana maskarada może być w efekcie hiperbolizacją kobiecości - to znaczy uwydatnieniem i wzmocnieniem cech kobiecych uznawanych za najbardziej właściwe tej płci i wizualnie pożądane. Jej efektem nie jest jednak afirmacja, lecz ujawnienie, że esencjalistycznie ujmowana kobiecość nie istnieje poza jej wizerunkiem i reprezentacją. Maskarada wykracza jednak poza estetykę, może być również rodzajem samoobrony lub protestu, a także sposobem radzenia sobie z tożsamością niemieszczącą się w społecznych oczekiwaniach.

Maskarada wykorzystuje znane kody normatywne, ale uruchamia je i przekształca na własny użytek.

54 P. Robertson, "The Kinda Comedy That Imitates Me". Mae West's Identification with the Feminist Camp, "Cinema Journal” 1993, t. 32, nr 2, s. 57. Zob. także eadem, Jak się robi kamp feministyczny?, przeł. P. Czapliński, [w:] Kamp. Antologia przekładów, red. P. Czapliński, A. Mizerka, Kraków 2012, s. 97.

${ }^{55}$ P. Robertson, „,The Kinda Comedy That Imitates Me”..., op. cit., s. 62. 
„Być sobą" - pisał Richard Schechner - to znaczy być sobą i zachowywać się niewymuszenie - jednak nawet takie zachowanie może zostać odebrane przez innych jako performans. „Zachowywać się jak...”, to znaczy przybrać czyjś wygląd (ubiór, zachowanie), głos i działania ${ }^{56}$.

Pojęcie maskarady we wskazanym wyżej rozumieniu można odnieść do cesarzowej Elżbiety. Odrzuciła ona rolę cesarzowej, rezygnując z zajęć i zadań, które z nią wiązano. Dla współczesnych zapewne szokujące było to, że Sisi „nie czuła szczęścia, będąc cesarzową" ${ }^{57}$ i nie rozumiała swoich powinności jako żona władcy. Zapewne była świadoma zarówno swojej nieadekwatności na wiedeńskim dworze, jak i krytyki czy nawet rozczarowania. W reakcji, w sensie dosłownym wypracowała własny wizerunek, będący niejako w kontrze do tego, jak chciało postrzegać ją otoczenie. Konstruując go, wykorzystała, lecz na swoich warunkach, estetykę wyrafinowanej kobiecości, sex appealu i lekkości, dość odległą od tradycyjnej roli macierzyńskiej i opiekuńczej „matki narodu”, jaką wiązano z żoną władcy. Warto jednak pamiętać, że posłużyła się wzorami, którymi były również podobizny kobiet lokowanych w ówczesnym demi-monde, a zatem nieakceptowanych w sferach, w których obracała się Elżbieta, i nierealizujących etosu rodzinnej kobiecości.

Elementem tej kreacji były wysmukła sylwetka, urodziwa twarz, charakterystyczna fryzura ułożona z bardzo długich włosów, ale również luksusowy i modny styl, który zapewne tylko w części oddaje jej najsłynniejszy portret. Te i podobne atrybuty składające się na kulturowo rozpoznawane piękno umożliwiły jej podjęcie zaplanowanej roli, ale sprawiały również, że wizerunek był trudny do skopiowania, co nie znaczy, że takich prób nie podejmowano. W trakcie rzadkich publicznych występów Elżbieta konsekwentnie realizowała wybraną rolę, wcielając się w „piękną cesarzową", limitując swoje podobizny czy ostatecznie uniemożliwiając powstanie takich, które dokumentowałyby niekorzystne zmiany wyglądu spowodowane naturalnym upływem czasu oraz konsekwencjami stosowanych przez nią głodówek i ekstremalnych treningów fizycznych.

${ }^{56}$ R. Schechner, Performatyka, przeł. T. Kubikowski, Wrocław 2006, s. 197.

${ }^{57}$ Parafrazuję tu fragment zdania biografa Sisi Egona Caesara Corti, który pozostawił wyidealizowany obraz cesarzowej, żony władcy, względem którego odczuwał lojalność. Zgodnie z jego tekstem hrabina Maria Festetic nie zauważała „głównej wady zarzucanej cesarzowej, a mianowicie braku zrozumienia dla wysokiej piastowanej godności, braku władczej dumy oraz poczucia szczęścia, że jest się cesarzową". Zob. E.C. Corti, Cesarzowa Elżbieta, op. cit., s. 177. 
Interesującą wskazówkę sugerującą, że Elżbieta mogła bawić się swym wizerunkiem, podała Juliana Vogel, wskazując, że stylizacja cesarzowej uwieczniona na obrazie Winterhaltera była kolorystycznym odwróceniem stroju - sukni, lecz również uczesania i gwiaździstych ozdób - jaki kilka lat wcześniej nosiła inna piękność, znana z ekstrawagancji i otoczona aurą femme fatale Virginia Oldoini, countessa Castiglione, w pewnym okresie kochanka cesarza Napoleona III. Jako kobieta-szpieg wysłana do Francji przez Camillo Cavoura, architekta zjednoczenia Włoch, działała na niekorzyść monarchii Habsburgów, której przedstawicielką była przecież - w powszechnej opinii Elżbieta $^{58}$. Zestawienie to tworzyło ironiczny kontrast. Są również przesłanki, że Elżbieta posługiwała się innymi odmianami ironii, czasem przechodzącymi w drwinę, komentując $w$ ten sposób składane jej hołdy, naśladujących ją ludzi i odnosząc się do swego męża - cesarza ${ }^{59}$. Ironia, rozumiana jako postawa intelektualna, pozwala zaznaczyć dystans, ale również - o ile jest odczytana - operując odwróconym znaczeniem, może jednocześnie coś podkreślić i banalizować, legitymizować i podważać. Wypowiedź ironiczna opiera się na kontekście sytuacyjnym, a jej intencjonalne znaczenie jest ukryte i odwrotne niż dosłownie przekazany sens. Jako taka jest również cechą kampu60.

Ostatecznie odtwarzanie skonstruowanej przez siebie roli stało się dla Elżbiety rodzajem przewrotnej tożsamościowej, subwersywnej gry - powielanie wzorców piękna w istocie było ich podważaniem. Mimo że impersonatorka dystansowała się od nich, czego wyrazem mogła być wspomniana ironia i autoironia, odbiorcy mogli nie odczytać jej intencji, a zatem kontestowane wzory mogą być postrzegane jako wyraz normy, naturalizowane, odtwarzane i rozpowszechniane.

\section{ZAKOŃCZENIE}

Fotografie i reprodukcje jej oficjalnych portretów posłużyły Elżbiecie do wykreowania własnego wizerunku. Paradoksalnie, w jego tworzeniu wykorzystywała ona możliwości, jakie dawała jej pozycja, finanse i wpływy cesarzowej, której rolę odrzucała. Nie godziła się ona, by stać się częścią

58 J. Vogel, The Double Skin..., op. cit., s. 229-231.

59 J.P. Bled, Franz Joseph, Oxford - Cambridge 1994, s. 242; B. Hamann, Cesarzowa Elżbieta, op. cit., s. 249; ibidem, s. 339.

${ }^{60}$ P. Robertson, Jak się robi kamp..., op. cit., s. 93. 
spektaklu, który odbywał się co dzień na dworze Franciszka Józefa, nie tylko nie udzielała się towarzysko, ale konsekwentnie stroniła od burzliwych wydarzeń politycznych, tak brzemiennych dla stabilności i przyszłości cesarstwa oraz - co nie jest przesadą - Europy. Udało jej się jednak stworzyć obraz nierozumianej, nieprzemijającej i melancholijnej Piękności. Intryguje on do dziś, przywołując obraz elegancji i dobrego smaku. Kojarzy się również z nadmiarowością i przesadnym wystylizowaniem, co w powiązaniu ze znanym faktem odrzucenia przez Elżbietę roli żony i matki sprawia, że jest on odczytywany jako mieszczący się w kategorii queer ${ }^{11}$.

Fascynacja cesarzową Sisi trwa. „W dzisiejszych czasach byłaby prawdopodobnie w ogóle »influencerką" par excellence. Rzadko kiedy ktoś tak precyzyjnie przemyślał, dopracował, ukształtował, wdrożył, realizował i podążał za własnym wizerunkiem"62.

\section{BIBLIOGRAFIA}

Bled J.P., Franz Joseph, Oxford - Cambridge 1994.

Bowers Bahney J., How a Master Thief Nearly Got Away with Austria's Most Famous Jewel, McFarland, CA 2015.

Corti E.C., Cesarzowa Elżbieta, przeł. Z. Peteresowa, Warszawa 1938.

Crankshaw E., The Fall of the House of Habsburg, New York, NY 1963.

Die Sterne der Kaiserin Elisabeth, https://www.koechert.com/sisis-sterne/ (dostęp 29 VII 2021).

Driessen Ch., Sisi privat. Faszinierendes Bild der Kaiserin in Köln, „Aachener Nachrichten” 23 X 2020, https://www.aachener-nachrichten.de/kultur/kunst/sisi-privat-faszinierendes-bildder-kaiserin-in-koeln_aid-54202847 (dostęp 5 III 2021).

Fischer-Lichte E., Estetyka performatywności, przeł. M. Borowski, M. Sugiera, Kraków 2008.

Freifeld A., Empress Elisabeth as Hungarian Queen, [w:] The Limits of Loyalty. Imperial Symbolism, Popular Allegiances, and State Patriotism in the Late Habsburg Monarchy, red. L. Cole, D. Unowsky, Brooklyn, NY 2009, s. 138-161.

Geschichte des Hauses Wittelsbach, https://haus-bayern.com/geschichte/ (dostęp 5 III 2021).

Gruber-Florek O., The Modern Monarch. Empress Elisabeth and the Visual Culture of Femininity 1850-1900. Dissertation submitted to the Graduate School-New Brunswick Rutgers, The State University of New Jersey 2021, https://rucore.libraries.rutgers.edu/rutgers-lib/37535/PDF/1/play/ (dostęp 6 III 2021).

Hamann B., Cesarzowa Elżbieta, przeł. J. Koźbiał, Warszawa 1999.

${ }^{61} \mathrm{H}$. Schlipphacke, Melancholy Empress. Queering Empire in Ernst Marischka's Sissi Films, "Screen” 2010, t. 51, nr 3, s. 232-255; eadem, [w:] Sissi's World. Empress Elisabeth in Memory and Myth, red. M.E. Hametz, H. Schlipphacke, New York, NY 2018, s. 215-246; S. Hochreiter, Sisi. A Double Reflection on a "Queer Icon”, [w:] Sissi's World..., op. cit., s. 247-274.

${ }^{62}$ A. Matzker, E. Schlesinger, Sissi (Sisi) privat..., op. cit. (dostęp 5 III 2021). 
Hochreiter S., Sisi. A Double Reflection on a "Queer Icon", [w:] Sissi's World. Empress Elisabeth in Memory and Myth, red. M.E. Hametz, H. Schlipphacke, New York, NY 2018.

Hoesick F., Powieść mojego życia, t. 1, Wrocław - Kraków 1959.

Joseph A., "A Wizard of Silks and Tulle". Charles Worth and the Queer Origins of Couture, "Victorian Studies" 2014, t. 56, nr 2, s. 257.

Judson P.M., The Habsburg Empire. A New History, Cambridge, MA 2016.

Kilka rysów z prywatnego życia panujq̨cych kobiet, „Dwutygodnik dla Kobiet” 23 VII 1881, R. 1, $\mathrm{nr} 22$.

Matzker A., Schlesinger E., Sissi (Sisi) privat - Bisher unbekannte Photoalben der Kaiserin, https://onlinemerker.com/sissi-privat-bisher-unbekannte-photoalben-der-kaiserin/ (dostęp 5 III 2021).

Menden A., Sisi und ihre Schönheiten-Alben, „Süddeutsche Zeitung” 26 X 2020, https://www. sueddeutsche.de/panorama/fotos-koeln-kaiserin-sisi-1.5092956 (dostęp 5 III 2021).

Muellner B., Empress Elisabeth and Her „Untidy" Collection, „Women's Studies” 2010, t. 39, s. 536-561.

Newton E., Wzorce ról, przeł. P. Czapliński, [w:] Kamp. Antologia przekładów, red. P. Czapliński, A. Mizerka, Kraków 2012, s. 469-490.

Robertson P., Jak się robi kamp feministyczny?, przeł. A. Matkowska, [w:] Kamp. Antologia przekładów, red. P. Czapliński, A. Mizerka, Kraków 2012, s. 92-117.

Robertson P., "The Kinda Comedy That Imitates Me". Mae West's Identification with the Feminist Camp, "Cinema Journal” 1993, t. 32, nr 2, s. 57-72.

Schechner R., Performatyka, przeł. T. Kubikowski, Wrocław 2006.

Schlipphacke H., Melancholy Empress. Queering Empire in Ernst Marischka's Sissi Films, „Screen" 2010, t. 51, nr 3, s. 232-255.

Schlipphacke H., Melancholy Empress: Queering Empire in Ernst Marischka's Sissi Films, [w:] Sissi's World. Empress Elisabeth in Memory and Myth, red. M.E. Hametz, H. Schlipphacke, New York, NY 2018, s. 215-246.

Schulte R., The Queen - A Middle-Class Tragedy. The Writing of History and the Creation of Myths in Nineteenth-Century France and Germany, "Gender \& History” 2002, t. 14, s. 266-293.

Sisi in Private. The Empress's Photo Albums October 24. 2020 - July 4. 2021 [wystawa], https:// www.museum-ludwig.de/en/exhibitions/sisi-privat-die-fotoalben-der-kaiserin.html (dostęp 5 III 2021).

Sisi's Photos Reveal an Emancipated Empress, https://www.dw.com/en/sisis-photos-reveal-an-emancipated-empress/a-55398188 (dostęp 5 III 2021).

Smolarski M., Miasto starych dzwonów, Kraków 1960.

Solski L., Wspomnienia, t. 2: 1893-1954, Kraków 1956.

Stender D., Sisi als Influencerin. Die Foto-Alben der Kaiserin im Kölner Museum Ludwig, wywiad z 23 X 2020, https://www.swr.de/swr2/kunst-und-ausstellung/sisi-als-influencerindie-foto-alben-der-kaiserin-im-koelner-museum-ludwig-100.html (dostęp 5 III 2021).

Vogel J., The Double Skin. Imperial Fashion in the Nineteenth Century, [w:] The Body of the Queen. Gender and Rule in Courtly World 1500-2000, red. R. Schulte, Brooklyn, NY 2006, s. 216-237.

\section{Czasopisma}

All Europe Shocked, „The Iola Register" 16 IX 1898, t. 32.

An Empress Slain, „Baxter Springs News” 17 IX 1898, t. 15.

Cesarzowa Elżbieta, „Bluszcz” 17 (29) IX 1898, R. 34, nr 39. 
„Czas" 12 VI 1867, R. 20, nr 133.

"Czas" 13 VI 1867, R. 20, nr 134.

Empress's Assassin Jeers at Low. Ten of His Camrades Arrested, „New York Journal and Advertiser" 12 IX 1898.

„Gazeta Kielecka” 21 IX 1989, R. 29, nr 75.

The Murdered Empress, „The Sun” 11 IX 1898.

„The Weekly Union Times” 29 VII 1892, t. XXIII.

\title{
THE BEAUTIFUL EMPRESS... ELIZABETH OF BAVARIA (SISI) AND HER PERFORMANCES
}

\begin{abstract}
The article presents Elisabeth of Austria (Sisi) - the wife of Franz Josef I. She went down in history as a beautiful and unhappy woman. „Beautiful Empress" would be the role that the heroine constructed for herself. Sisi had consistently performed her role by producing a series of public performances and actively creating and directing her own public image. In doing so, she took advantage of the opportunities afforded by her position, finances and influence as empress. Ultimately, the image she created and sought to control overshadowed the historical figure of the empress's wife, and elements of this image still continue to function in culture today.
\end{abstract}

Keywords: empress Elisabeth of Austria, Sisi, Habsburg Empire, image, feminity imagery, public performances 